J. Amer. Soc. Hort. Sci. 116(1):63-67. 1991.

\title{
Forcing Characteristics of Easter Lily Bulbs Exposed to Elevated-ethylene and -carbon Dioxide and Low-oxygen Atmospheres
}

Timothy A. Prince and Maria S. Cunningham ${ }^{2}$

Department of Horticulture, Ohio Agricultural Research and Development Center, The Ohio State University, Columbus, $\mathrm{OH} 43210$

Additional index words. Lilium longiflorum, potted flowering plants, postharvest handling

\begin{abstract}
Exposure of bulbs of Easter Lily (Lilium longiflorum Thunb.) to a maximum of $2 \mu$ ethylene/liter during vernalization delayed flowering by 5 to 7 days and decreased the number of flower buds. Ethylene exposure for 5 days at $21 \mathrm{C}$ after vernalization accelerated shoot emergence and flowering by up to 3 days. No floral or plant abnormalities were observed after bulb exposure to ethylene. Exposure to atmospheres with $0 \%, 0.5 \%$, or $1 \%$ O at 21C for up to 2 weeks before or 10 days after vernalization did not "significantly impair subsequent bulb forcing. Storage in $1 \% \mathrm{o}_{2}$ at $21 \mathrm{C}$ for 1 week before vernalization resulted in nearly one additional secondary bud initiated per plant. Exposure to up to $15 \% \mathrm{CO}_{2}$ at $21 \mathrm{C}$ for up to 2 weeks before or 10 days after vernalization did not significantly impair subsequent forcing.
\end{abstract}

We previously reported that lining of cases used for handling and vernalization of bulbs of Easter lily with polyethylene (PE) accelerates floral shoot emergence, floral initiation, and flowering compared to bulbs from nonlined cases (Prince and Cunningham, 1990). One of the reasons for these responses is that $\mathrm{PE}$ lining greatly reduces bulb moisture loss during handling, shipping, and vernalization. Because PE liners are a barrier to gas exchange, their use could elevate $\mathrm{CO}_{2}$,or ethylene or reduce $\mathrm{O}_{2}$ concentrations in the cases during handling.

Floral abortion and. reduction of rooting have been cited as serious symptoms caused by ethylene accumulated in bulbs (Kamerbeek and De Munk, 1976). In tulip bulbs, ethylene production was increased as cold programming progressed (Prince et al., 1982). Ethylene production by lily bulbs, in addition to any microbial source, could result in accumulation of ethylene in the cases during vernalization or during handling periods between vernalization and planting.

A few researchers have exposed lily bulbs to altered $\mathrm{O}_{2}$ and $\mathrm{CO}_{2}$ atmospheres. Thornton (1939) found that exposure to 5\% $\mathrm{O}_{2}$ delayed shoot emergence with noncooled bulbs. Later studies (Thornton and Imle, 1941) found that $\mathrm{O}_{2}$ concentration as low as $2 \%$ during storage of bulbs for 28 days at $3.5 \mathrm{C}$ had no effect, but that $40 \% \mathrm{CO}_{2}$ delayed shoot emergence, growth, and flowering. Stuart et al. (1970) reported that lily bulbs tolerated anaerobic conditions $\left(100 \% \mathrm{~N}_{2}\right)$ for up to 12 weeks at 10,5 , or OC without apparent damage. Concentrations of $0.25 \% \mathrm{O}_{2}$ during cold storage did delay flowering.

Oxygen depletion and $\mathrm{CO}_{2}$ accumulation in cases would be most likely to occur before vernalization and during a holding period after vernalization. Temperatures are likely to be highest during these two handling periods, resulting in high respiration rates. Little is known about the possible effects of these atmospheric gases on the vernalization and subsequent forcing re-

Received for publication 14 Aug. 1989. Salaries and research support provided by state and federal funds appropriated to the Ohio Agricultural Research and Development Center, The Ohio State Univ. Manuscript no. 246-89. We thank the Fred C. Gloeckner Foundation and Hastings Bulb Growers for their financial support of this research. The cost of publishing this paper was defrayed in part by the payment of page charges. Under postal regulations, this paper therefore must be hereby marked advertisement solely to indicate this fact.

'Assistant Professor.

${ }^{2}$ Research Technician. sponse of the lily bulb. Our studies examined the forcing response of the bulbs to these gases at these times and the effects of ethylene during and after vernalization.

\section{Materials and Methods}

Studies of bulb exposure to reduced $\mathrm{O}_{2}$ and elevated ethylene were conducted in 1987-88 and those of exposure to $\mathrm{CO}_{2}$ in 1988-89. Bulbs of 'Nellie White' (23 to $25 \mathrm{~cm}$ in circumference) were grown in Oregon, harvested by accepted commercial practice, and packed in cases on 24 Sept. 1987 and 27 Sept. 1988. Bulbs were held in warehouse storage at 14 to $17 \mathrm{C}$ until 9 Oct. 1987 and 6 Oct. 1988, when they were shipped to Columbus, Ohio, in refrigerated trucks. Transit required 6 days at 2 to $5 \mathrm{C}$ in 1987 and 4 days at 8 to $13 \mathrm{C}$ in 1988 . After arrival, bulbs were held at $21 \mathrm{C}$ until experiments began. All bulbs were vernalized for 6 weeks at $4.5 \mathrm{C}$ before, during, or after treatment with various gas mixtures to be described. Gases were humidified to $>95 \%$ RH (General Eastern Humidity Monitor Model 800B, Watertown, Mass.) and were passed over bulbs held in the dark

Bulbs were planted in 1.4-liter pots containing Metro-Mix 350 (W.R. Grace, Cambridge, Mass). Bulbs were forced according to standard commercial practice (Tayama et al., 1988). The night minimum was maintained at $15.5 \mathrm{C}$ with a maximum growing medium temperature of $18.5 \mathrm{C}$ during rooting and floral initiation. Greenhouse ventilation began at $21 \mathrm{C}$ after floral initiation.

Ethylene exposure. Bulbs were exposed to ethylene during and after vernalization in two separate experiments. On 27 Oct. 1987 , bulbs were sprayed to run-off $(\approx 5 \mathrm{ml} / \mathrm{bulb})$ with a solution of silver thiosulfate (STS) at $2 \mathrm{~mm} \mathrm{Ag}^{+}$or with water and were allowed to dry for several hours. Humidified air containing $0.1-0.2$ or 1.0-2.0 $\mu \mathrm{l}$ ethylene/liter (Salveit, 1978) or ethylene-free air was passed ( 8 liter-hr $\left.{ }^{-1}\right)$ through 40 -liter cans used for treating the bulbs during vernalization. Ethylene levels exiting the cans were verified periodically by gas chromatography. Three replicate cans for each ethylene level (nine total cans) were placed randomly in the vernalization room. Two mesh bags containing 16 STS-treated or 16 water-treated bulbs were placed randomly in each can in a split-plot design. Following treatment, bulbs were planted and placed on the greenhouse bench for forcing. At 2 and 4 weeks after planting, three STS-treated and three water-treated bulbs from each can were 
Table 1. Forcing characteristics of 'Nellie White' lily bulbs after silver thiosulfate (STS) pretreatment and ethylene exposure during 6 weeks of vernalization at $4.5 \mathrm{C}$.

\begin{tabular}{|c|c|c|c|c|c|c|c|c|c|}
\hline \multirow[b]{3}{*}{ Pretreatment } & \multirow{3}{*}{$\begin{array}{l}\text { Ethylene } \\
\text { concn } \\
\left(\mu \mathrm{l} \cdot \text { liter }^{-1}\right)\end{array}$} & \multirow{2}{*}{\multicolumn{2}{|c|}{$\begin{array}{c}\text { Root } \\
\text { elongationz } \\
\text { (rating) }\end{array}$}} & \multirow{3}{*}{$\begin{array}{l}\text { Basal leaf } \\
\text { elongation } \\
\text { (rating) }\end{array}$} & \multirow{3}{*}{$\begin{array}{l}\text { Leaf } \\
\text { no. }\end{array}$} & \multicolumn{3}{|c|}{ Days from planting until } & \multirow{3}{*}{$\begin{array}{l}\text { No. } \\
\text { floral } \\
\text { buds }\end{array}$} \\
\hline & & & & & & Shoot & Floral buds & First & \\
\hline & & 2 wk & 4. wk & & & emergence & visible & bud open & \\
\hline \multirow[t]{3}{*}{ Water } & 0 & 2.4 & 2.5 & 2.6 & 89 & 26.1 & 84.2 & 114 & 6.4 \\
\hline & $0.1-0.2$ & 1.8 & 3.5 & 2.8 & 96 & 26.0 & 88.7 & 119 & 6.3 \\
\hline & $1.0-2.0$ & 1.7 & 3.8 & 2.9 & 98 & 26.8 & 90.8 & 121 & 5.9 \\
\hline \multirow[t]{2}{*}{ STS } & 0 & 1.9 & 3.2 & 2.3 & 92 & 27.5 & 86.2 & 116 & 6.3 \\
\hline & $1.0-2.0$ & 1.3 & 3.6 & 2.7 & 99 & 27.4 & 91.8 & 121 & 5.8 \\
\hline SEM ${ }^{w}$ & & 0.2 & 0.2 & 0.1 & 2 & 1.6 & 1.5 & 1.5 & 0.2 \\
\hline \multicolumn{10}{|l|}{ F tests } \\
\hline STS & & $*$ & NS & $*$ & NS & NS & NS & NS & NS \\
\hline Ethylene vs. no ethylene & & NS & NS & NS & $* *$ & NS & NS & $* *$ & * \\
\hline STS $\times$ (ethylene vs. no ethylene) & & NS & $*$ & NS & NS & NS & NS & NS & NS \\
\hline
\end{tabular}

${ }^{2}$ Basedon 1 (poor) to 7 (excellent) scale (see text).

${ }^{y}$ Based on a 3 -point scale with $1=$ short to $3=$ long leaves.

Includes primary and secondary buds.

"Standard error of a mean.

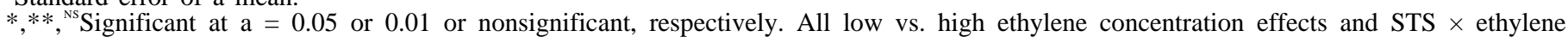
concentration interactions were nonsignificant.

unpotted and rated for root growth on a 7-point scale, with 0 indicating no root growth and 7 indicating excellent growth, as described by Prince and Cunningham (1990). The remaining 20 bulbs (half STS-treated) in each can were forced to flowering. Days from planting until 'shoot emergence above the medium, number of visible buds, and date of flowering (opening of first flower bud) were recorded. At flowering, plant height, number of leaves and floral buds, and degree of elongation of the lower leaves were determined. A basal leaf rating was assigned to each plant as follows: $1=$ short stubby leaves, $2=$ mediumlength leaves, or $3=$ long leaves (extending over pot rim). A photograph of representative plants of each rating was used for standardization of the rating scale. (Prince and Cunningham, 1990).

For postvernalization ethylene exposure, bulbs were pretreated with STS as described above and then vernalized in ventilated PE bags of moist peat for 6 weeks, beginning 30 Oct. 1987. They then were exposed to ethylene during holding at $21 \mathrm{C}$ for 5 days using the same experimental design as described above.

Low-oxygen exposure. Bulbs were continuously exposed to atmospheres of $0 \%, 0.5 \% \pm 0.05 \%$, or $1 \% \pm 0.05 \% \mathrm{O}_{2}$ or to a control atmosphere of $19.25 \%$ to $19.35 \% \mathrm{O}_{2}$ during holding for 1 or 2 weeks at $21 \mathrm{C}$. Atmospheres were created by mixing controlled flows of humidified $\mathrm{N}_{2}$ and $\mathrm{O}_{2}$. Two replicate 12liter plastic containers, each containing 10 bulbs, were used for each treatment-duration combination in a completely randomized design. Atmospheres were passed through each container at 12 liter $\mathrm{hr}^{-1}$ and $\mathrm{O}_{2}$ concentrations exiting the containers were verified periodically using a paramagnetic $\mathrm{O}_{2}$ analyzer (Model 570A, Servomex, Norwood, Mass.). Treatments began 1 week apart (21 Oct. and 28 Oct. 1987) for two durations so that all bulbs could begin vernalization on the same date (4 Nov. 1987). After exposure, bulbs were vernalized in ventilated PE bags of moist peat and planted. Evaluation of growth and flowering was as described previously, except that a 3-point root rating scale was used at flowering, with 1 indicating poor rooting and 3 excellent.
Table 2. Forcing characteristics of 'Nellie White' lily bulbs after silver thiosulfate (STS) pretreatment, vernalization, and postvernalization exposure to ethylene for 5 days at $21 \mathrm{C}$.

\begin{tabular}{|c|c|c|c|c|c|}
\hline \multirow[b]{2}{*}{ Pretreatment } & \multirow{2}{*}{$\begin{array}{c}\text { Ethylene } \\
\text { concn } \\
\left(\mu \mathrm{l} \cdot \mathrm{liter}^{-1}\right)\end{array}$} & \multicolumn{3}{|c|}{ Days from planting until } & \multirow{2}{*}{$\begin{array}{l}\text { No. } \\
\text { floral } \\
\text { buds }\end{array}$} \\
\hline & & $\begin{array}{c}\text { Shoot } \\
\text { emergence }\end{array}$ & $\begin{array}{c}\text { Floral buds } \\
\text { visible }\end{array}$ & $\begin{array}{c}\text { First } \\
\text { bud open }\end{array}$ & \\
\hline \multirow[t]{3}{*}{ Water } & 0 & 25.4 & 91 & 120 & 5.5 \\
\hline & $0.1-0.2$ & 24.2 & 90 & 119 & 5.0 \\
\hline & $1.0-2.0$ & 22.1 & 88 & 117 & 4.7 \\
\hline \multirow[t]{3}{*}{ STS } & 0 & 25.9 & 90 & 120 & 5.3 \\
\hline & $0.1-0.2$ & 22.7 & 88 & 118 & 5.4 \\
\hline & $1.0-2.0$ & 23.5 & 91 & 120 & 4.3 \\
\hline $\mathrm{SEM}^{\mathrm{y}}$ & & 0.8 & 0.9 & 0.9 & 0.3 \\
\hline \multicolumn{6}{|l|}{ F tests } \\
\hline \multirow{2}{*}{\multicolumn{2}{|c|}{$\begin{array}{l}\text { Ethylene vs. no ethylene } \\
\text { Low vs. high ethylene } \\
\text { concn }\end{array}$}} & $*$ & NS & NS & NS \\
\hline & & NS & NS & NS & NS \\
\hline \multirow{2}{*}{\multicolumn{2}{|c|}{ STS $\times$ (low vs. high }} & & & & \\
\hline & & NS & * & * & NS \\
\hline
\end{tabular}

${ }^{2}$ Includes primary and secondary buds.

'Standard error of a mean.

$*, * *{ }^{\mathrm{Ns}}$ Significant at $\alpha 0.05$ or 0.01 or nonsignificant, respectively. All STS main effects and STS $\times$ (ethylene vs. no ethylene) interactions were nonsignificant.

For postvernalization exposure, vernalization of bulbs was started in moist peat in shipping cases on 23 Oct. 1987. Treatments were begun on removal, when $\mathrm{O}_{2}$ levels as described above were applied during holding of bulbs at $21 \mathrm{C}$ for 5 or 10 days before planting.

Carbon dioxide exposure. Two studies were conducted identically to the low- $\mathrm{O}_{2}$ studies, except that atmospheres were $5 \%$, $10 \%$, and $15 \%$, all $\pm 1 \% \mathrm{CO}_{2}$, or controls at $0 \%$ to $1.5 \% \mathrm{CO}_{2}$. Atmospheres were created by mixing humidified air and $\mathrm{CO}_{2}$ and were passed through each container at 2.5 liter $\cdot \mathrm{hr}^{-1}$. Carbon dioxide concentrations at the container exits were verified by gas chromatography. For $\mathrm{CO}_{2}$ exposure before vernalization, treatments began on 18 Oct. 1988 and 29 Nov. 1988 for bulbs treated after vernalization. 
Table 3. Forcing characteristics of 'Nellie White' lily bulbs after low- $\mathrm{O}_{2}$ exposure at $21 \mathrm{C}$ for 1 or 2 weeks before vernalization.

\begin{tabular}{|c|c|c|c|c|c|c|c|c|}
\hline \multirow{3}{*}{$\begin{array}{l}\text { Oxygen } \\
\text { concn } \\
(\%) \\
\end{array}$} & \multirow{3}{*}{$\begin{array}{l}\text { Duration } \\
\text { (wk) }\end{array}$} & \multirow{3}{*}{$\begin{array}{c}\text { Basal leaf } \\
\text { elongation } \\
\text { (rating) }\end{array}$} & \multirow{3}{*}{$\begin{array}{l}\text { Leaf } \\
\text { no. }\end{array}$} & \multirow{3}{*}{$\begin{array}{c}\text { Root } \\
\text { elongation } \\
\text { (rating) }\end{array}$} & \multicolumn{2}{|c|}{ Days from planting to } & \multirow{2}{*}{\multicolumn{2}{|c|}{ No. floral buds }} \\
\hline & & & & & \multirow{2}{*}{$\begin{array}{c}\text { Shoot } \\
\text { emergence }\end{array}$} & \multirow{2}{*}{$\begin{array}{c}\text { Floral buds } \\
\text { visible }\end{array}$} & & \\
\hline & & & & & & & Primary & Secondary \\
\hline 19.3 & 1 & 2.6 & 104 & 3.0 & 22.2 & 88.0 & 4.9 & 0.8 \\
\hline 1.0 & & 2.4 & 95 & 3.0 & 25.2 & 84.3 & 5.0 & 1.6 \\
\hline 0.5 & & 2.4 & 93 & 2.9 & 27.5 & 87.1 & 4.8 & 0.9 \\
\hline 0.0 & & 2.4 & 103 & 2.7 & 21.9 & 85.5 & 4.8 & 0.7 \\
\hline 19.3 & 2 & 2.7 & 105 & 3.0 & 23.8 & 89.4 & 5.0 & 1.1 \\
\hline 1.0 & & 2.2 & 97 & 2.9 & 23.9 & 83.7 & 4.9 & 1.5 \\
\hline 0.5 & & 2.3 & 96 & 2.9 & 24.3 & 84.9 & 4.9 & 1.0 \\
\hline 0.0 & $\therefore$ & 1.8 & 97 & 3.0 & 27.9 & 87.2 & 5.0 & 0.8 \\
\hline SEM $^{x}$ & & 0.2 & 2 & 0.07 & 0.8 & 1.6 & 0.1 & 0.2 \\
\hline \multicolumn{9}{|c|}{$\mathrm{F}$ tests } \\
\hline \multicolumn{9}{|c|}{ Oxygen concn } \\
\hline 19.3 & hers & $*$ & $* *$ & NS & $*$ & $*$ & NS & NS \\
\hline 0 vs & & NS & $*$ & NS & NS & NS & NS & $*$ \\
\hline 0.5 & & NS & NS & NS & NS & NS & NS & $*$ \\
\hline \multicolumn{9}{|c|}{ Oxygen concn $\times$ duration } \\
\hline 19.3 & hers & NS & NS & NS & NS & NS & NS & NS \\
\hline 0 vs & & NS & $*$ & $*$ & $* *$ & NS & NS & NS \\
\hline 0.5 & & NS & NS & NS & NS & NS & NS & NS \\
\hline
\end{tabular}

${ }^{2}$ Based on a 3-point scale with $1=$ short to $3=$ long leaves.

${ }^{y}$ Rating scale of $1=$ poor to $3=$ excellent.

${ }^{\mathrm{x}}$ Standard error of a mean.

$*, * *,{ }^{\text {NS }}$ Significant at $\alpha=0.05$ or 0.01 , or nonsignificant, respectively. All duration main effects were nonsignificant.

Statistical analysis. Analysis of variance was conducted for each study. Main effects and interactions of each factorial treatment arrangement were examined. Single-degree-of-freedom contrasts were used to make more-specific comparisons. Where split-plots were used, appropriate error terms were calculated and used for $\mathrm{F}$ tests.

\section{Results}

Ethylene exposure. Ethylene exposure during vernalization reduced root growth measured at 2 weeks. Ethylene enhanced the root growth measured at 4 weeks on water-treated bulbs, but only the high concentration of ethylene increased root growth at 4 weeks after planting of STS-treated bulbs (Table 1). STS decreased basal leaf elongation. Ethylene exposure delayed flowering by 5 to 7 days and increased leaf numbers at harvest. The delay in flowering occurred between shoot emergence and flowering, since shoot emergence was not delayed by ethylene exposure." The number of floral buds was decreased by 0.5 at the high exposure level. STS had no effect on flowering date nor on leaf or bud number.

Ethylene exposure after vernalization (Table 2) accelerated shoot emergence and days to visible bud and flower. STS interacted by reducing these effects somewhat. Bud number was reduced by about one bud per plant, although the ethylene effect was not significant $(\alpha=0.057)$.

Low-oxygen exposure. Low- $\mathrm{O}_{2}$ exposure of bulbs before vernalization reduced leaf number and basal leaf elongation observed at flowering (Table 3). Oxygen levels of $0.5 \%$ and $0 \%$ decreased root elongation at flowering compared to control bulbs after 1 week of exposure. Exposure to $0.5 \%$ or $1 \% \mathrm{O}_{2}$ for 1 week delayed shoot emergence, but $0 \%$ did not delay emergence compared to controls. After 2 weeks of exposure, only $0 \% \mathrm{O}_{2}$ delayed emergence. The low or $0 \% \mathrm{O}_{2}$ treatments for both 1 and 2 weeks reduced the number of days to visible bud com-
Table 4. Forcing characteristics of 'Nellie White' lily bulbs after vernalization and low- $\mathrm{O}_{2}$ exposure for 5 and 10 days at $21 \mathrm{C}$.

\begin{tabular}{|c|c|c|c|}
\hline $\begin{array}{l}\text { Oxygen } \\
\text { concn } \\
(\%) \\
\end{array}$ & $\begin{array}{c}\text { Duration } \\
\text { (days) }\end{array}$ & $\begin{array}{c}\text { Basal leaf } \\
\text { elongation } \\
\text { (rating) }\end{array}$ & $\begin{array}{c}\text { Days from } \\
\text { planting to } \\
\text { shoot } \\
\text { emergence }\end{array}$ \\
\hline 19.3 & 5 & 2.4 & 26.6 \\
\hline 1.0 & & 2.0 & 27.6 \\
\hline 0.5 & & 1.6 & 27.9 \\
\hline 0.0 & & 2.1 & 29.1 \\
\hline 19.3 & 10 & 2.1 & 26.8 \\
\hline 1.0 & & 1.7 & 30.2 \\
\hline 0.5 & & 1.5 & 31.0 \\
\hline 0.0 & & 1.9 & 32.7 \\
\hline SEM $^{y}$ & & 0.1 & 0.8 \\
\hline \multicolumn{4}{|l|}{$F$ tests } \\
\hline \multicolumn{4}{|c|}{ Oxygen concn } \\
\hline 19.3 & & $* *$ & $* *$ \\
\hline $0 \mathrm{vs}$ & & NS & $*$ \\
\hline 0.5 & & * & NS \\
\hline Durati & & * & $* *$ \\
\hline
\end{tabular}

${ }^{2}$ Based on 3 -point scale with $1=$ short to $3=$ long leaves.

${ }^{y}$ Standard error of a mean.

${ }^{*}, * *{ }^{\mathrm{NS}}$ Significant at $\alpha=0.05$ or 0.01 or nonsignificant, respectively. All interactions were nonsignificant.

pared to controls. Exposure to $1 \% \mathrm{O}_{2}$ for 1 week resulted in the addition of one floral bud per plant. The increased number of buds (Table 3) was due to an additional secondary bud (Wilkins, 1980). All plants forced from low- and $0 \% \mathrm{O}_{2}$-treated bulbs appeared normal. Exposure to low $\mathrm{O}_{2}$ after vernalization reduced leaf elongation and delayed shoot emergence, but had no other significant effects (Table 4).

Carbon dioxide exposure. Exposing bulbs to $5 \%, 10 \%$, or $15 \% \mathrm{CO}_{2}$ before vernalization had very few effects on subse- 
Table 5. Forcing characteristics of 'Nellie White' lily bulbs after $\mathrm{CO}_{2}$ exposure at $21 \mathrm{C}$ for 1 or 2 weeks before vernalization.

\begin{tabular}{|c|c|c|c|c|c|c|}
\hline \multirow{2}{*}{$\begin{array}{l}\mathrm{CO}_{2} \\
\text { concn }^{2} \\
(\%)\end{array}$} & \multirow[b]{2}{*}{$\begin{array}{c}\text { Duration } \\
\text { (wk) }\end{array}$} & \multirow{2}{*}{$\begin{array}{c}\text { Basal leaf } \\
\text { elongation } \\
\text { (rating) }\end{array}$} & \multirow[b]{2}{*}{$\begin{array}{c}\text { Leaf } \\
\text { no. }\end{array}$} & \multicolumn{3}{|c|}{ Days from planting until } \\
\hline & & & & $\begin{array}{c}\text { Shoot } \\
\text { emergence }\end{array}$ & $\begin{array}{c}\text { Floral buds } \\
\text { visible }\end{array}$ & $\begin{array}{c}\text { First bud } \\
\text { open }\end{array}$ \\
\hline Control & 1 & 2.3 & 95 & 28.9 & 92.1 & 124.6 \\
\hline 5 & & 2.2 & . 96 & 30.7 & 93.0 & 124.1 \\
\hline 10 & & 2.1 & 91 & 30.5 & 93.0 & 125.3 \\
\hline 15 & & 2.4 & 92 & 27.1 & 89.2 & 121.0 \\
\hline Control & 2 & 2.1 & 93 & 27.6 & 88.4 & 122.1 \\
\hline 5 & & 2.0 & 91 & 28.1 & 88.2 & 121.6 \\
\hline 10 & & 2.1 & 91 & 27.7 & 89.3 & 122.3 \\
\hline 15 & & 2.1 & 89 & 26.8 & 86.8 & 119.4 \\
\hline SEM $^{x}$ & & 0.1 & 1.4 & 1.1 & 1.0 & 1.4 \\
\hline \multicolumn{7}{|l|}{$F$ tests } \\
\hline \multicolumn{7}{|c|}{$\mathrm{CO}_{2}$ concn } \\
\hline Cor & . vs. any & NS & NS & NS & NS & NS \\
\hline Con & n linear & * & NS & NS & * & NS \\
\hline Durati & & ${ }^{*}$ & * & $*$ & $* *$ & * \\
\hline
\end{tabular}

${ }^{2}$ Air controls had $0 \%$ to $1.5 \% \mathrm{CO}_{2}$ at the exit ports.

${ }^{\mathrm{y}}$ Based on 3 -point scale with $1=$ short to $3=$ long leaves.

${ }^{\mathrm{x}}$ Standard error of a mean.

$*, * *{ }^{\text {Ns }}$ Significant at $\alpha=0.05$ or 0.01 or nonsignificant, respectively. All quadratic concentration effects and interactions were nonsignificant.

quent forcing (Table 5). Days to visible bud were reduced 2 to 3 days by the highest $\mathrm{CO}_{2}$ level, but the resulting reduction in days to flower was not significant. Regardless of the $\mathrm{CO}_{2}$ content of the gas flowering over the bulbs, 2 weeks of ventilation reduced basal leaf elongation, leaf number, and days to shoot emergence, to visible "bud and to flowering compared to 1 week of ventilation (Table 5).

Exposure to $\mathrm{CO}_{2}$ during 10 days at $21 \mathrm{C}$ after vernalization delayed flowering from from 2 to 5 days compared to bulbs held in air for 10 days, but $\mathrm{CO}_{2}$ caused no other significant effects, Regardless of $\mathrm{CO}_{2}$ level, ventilation for 10 days reduced days to visible bud and flower by 2 days compared to 5 days of ventilation. Ranges of treatment means were 1.4-1.8 (basal leaf rating), 79-82 (leaf number), 2.8-3.0 (root rating), 15-17 (days to emergence), 72-77 (days to visible bud), 103-108 (days to flower), and 6.2-6.8 (bud number).

\section{Discussion}

We have measured ethylene levels ranging from 0.05 to 0.1 $\mu \mathrm{l} \cdot$ liter $^{-1}$ in internal gas samples vacuum-extracted from healthy bulbs just after removal from 6 weeks of vernalization (unpublished data). We do not know whether this ethylene is from bulb tissue or microorganisms. Our current results indicate that these levels could result in some delay in flowering, and reduced flower number on a commercial scale. However, ethylene does not appear to play a major role in the bulb developmental processes studied. We did not observe floral deformities or bud abortion as we observed on Easter lily plants exposed to ethylene just before bud opening (Prince et al., 1986). Bulbs such as tulips exhibit bulb gummosis, bud abortion, floral deformity, total shoot abortion, and greatly reduced rooting on exposure of bulbs to similar levels of ethylene that we used (Kamerbeek and DeMunk, 1976). The lack of floral and shoot abortion on exposure of lily bulbs to ethylene could be due to the vegetative state of the lily shoot during and immediately after vernalization compared to the reproductive state of the tulip shoot before cold treatment. The reasons for the lack of bulb gummosis and severe root growth inhibition in the lily bulb are unknown.

Swart (1980) found that bulb immersion in STS just before planting greatly protected cut flowers of 'Enchantment' lily against exogenous ethylene. She did not expose bulbs to ethylene, so a direct comparison to her work is impossible. However, our earlier work (Prince et al., 1986), showing that STS plant sprays reduce bud abortion on Easter lily plants cold stored or exposed to ethylene, suggests that bulb dips might function as observed by Swart (1980). Comparison of our earlier study (Prince et al., 1986) with our present data (Tables 1 and 2) suggests that plants near flowering are more susceptible to ethylene than bulbs themselves. Therefore, STS application to bulbs is not needed to protect bulbs from ethylene exposure, but that some form of STS application can be useful commercially for protecting the flowering plants.

These studies have demonstrated a high degree of tolerance of lily bulbs to low and virtual lack of $\mathrm{O}_{2}$, and to elevated $\mathrm{CO}_{2}$ environments at $21 \mathrm{C}$ both before and after vernalization. These results extend the observations of Stuart et al. (1970), who found lily bulbs tolerant to anaerobic conditions at low temperatures. Rhizomes of Iris pseudacorus L. have also been shown to survive anoxia for 7 days at 22C (Crawford, 1984). Lily bulbs removed from $0 \% \mathrm{O}_{2}$ had a fermentation odor, suggesting anaerobiosis. Regardless, the bulbs survived a period without $\mathrm{O}_{2}$ that did not impair their subsequent forcing characteristics. The delay in emergence from bulbs exposed to low- or nonoxygenated conditions (Table 4) could have been due to inhibition of respiration or metabolize transport from the bulb scales to the elongating shoot.

The cause of the increased bud count from $1 \% \mathrm{O}_{2}$ storage (Table 3) is unknown. Perhaps an anti-ethylene effect or conservation of respiratory substrates was involved. The prospect that a period of low- $\mathrm{O}_{2}$ exposure before bulb vernalization could be used to increase bud number deserves further investigation.

These studies have shown that low $\mathrm{O}_{2}$ and elevated $\mathrm{CO}_{2}$ concentrations that may develop in PE-lined cases of bulbs before 
or after vernalization would not likely be detrimental to bulb forcing. Ethylene accumulations could have negative effects if the bulbs are mishandled, but generally the effects would be minor. Therefore, concerns about the gaseous environment in a PE-lined case should not limit its commercial adoption for handling lily bulbs.

\section{Literature Cited}

Crawford, R.M.M. 1984. Anaerobic respiration and flood tolerance in plants, p. 67-75. In: J.M. Palmer (ed.). The physiology and biochemistry of plant respiration. Cambridge Univ. Press, Cambridge, U.K.

Kamerbeek, G.A. and W.J. De Munk. 1976. A review of ethylene effects-in bulbous plants. Scientia Hort. 4:101-115.

Prince, T.A. and M.S. Cunningham. 1990. Response of Easter lily bulbs to peat moisture content and the use of peat or polyethylenelined cases during handling and vernalization. J. Amer. Soc. Hort. Sci. 115:68-72.

Prince, T. A., R.C. Herner, and A.A. De Hertogh. 1982. Increases in ethylene and carbon dioxide production of Tulipa gesneriana L. 'Prominence' after completion of the cold-requirement. Scientia Hort. $16: 77-83$
Prince, T. A., M.S. Cunningham, and J.S. Peary. 1986. Floral and foliar quality of potted Easter Lilies after STS or phenidone application, refrigerated storage, and simulated boxed shipment. J. Amer. Soc. Hort. Sci. 112(3):469-473.

Saltveit, M.E. 1978. Simple apparatus for diluting and dispensing trace concentrations of ethylene in air. HortScience 13:249-251.

Stuart, N. W., C.S. Parsons, and C.J. Gould. 1970. The influence of controlled atmospheres during cool storage on the subsequent flowering of Easter lilies and bulbous iris. HortScience 5:356.

Swart, A. 1980. Quality of Lilium "Enchantment" flowers as influenced by season and silver thiosulphate. Acts Hort. 113:4549.

Thornton, N.C. 1939. Development of dormancy in lily bulbs. Contrib. Boyce Thompson Inst. 10:381-388.

Thornton, N.C. and E.P. Imle. 1941. Effect of mixtures of oxygen and carbon dioxide on the development of dormancy in Easter lilies. Contrib. Boyce Thompson Inst. 38:708.

Tayama, H. K., T.A. Prince, R.K. Lindquist, and C.C. Powell. 1988. Essentials of potted lily culture, Easter, March 26, 1989. Ohio Florists Brd. 708.

Wilkins, H.F. 1980. Easter lilies, p. 327-352. In: R.A. Larson (ed.). Introduction to floriculture. Academic, New York. 